\title{
MORPHOLOGY OF GALLS INDUCED BY WOOLLY APPLE APHID ON APPLE
}

\author{
M. SANDANAYAKA, P. SUTHERLAND and M. HEFFER \\ HortResearch, Private Bag 92169, Auckland, New Zealand \\ Corresponding author: msandanayaka@hortresearch.co.nz
}

Feeding of the woolly apple aphid Eriosoma lanigerum (Hausmann) on apple (Malus spp.) induces gall formation on aerial and underground parts of the trees. A single aphid can induce a gall and reproduce parthenogenetically to develop a colony of hundreds of aphids feeding on the same gall. During growth of the colony, the size of the gall also increases, allowing hundreds of individuals to feed for several months. Histological studies indicate that the gall is produced by a proliferation of xylem tissue that has not undergone secondary thickening or lignification of cell walls. Hence the cell walls of gall tissue remain thin and the gall has a soft and spongy texture. Since woolly apple aphid is a phloem feeder, it may not feed on the soft gall tissue. The proliferation of xylem tissue increases the circumference of the stem, which would facilitate greater access of the aphid colony to the phloem tissues of the host tree.

\section{OVIPOSITION PREFERENCE OF CNEPHASIA JACTATANA WALKER (LEPIDOPTERA: TORTRICIDAE) ON KIWIFRUIT}

\author{
A. JIMÉNEZ-PÉREZ ${ }^{1}$ and Q. WANG \\ Institute of Natural Resources, Massey University, \\ Private Bag 11222, Palmerston North \\ ${ }^{1}$ Permanent Address: CeProBi-IPN. P.O. Box 24, Yautepec, \\ Morelos. 62730. México \\ Corresponding author: Q.Wang@massey.ac.nz
}

The oviposition site preference of Cnephasia jactatana Walker, an important pest of kiwifruit, was investigated at $20 \pm 2^{\circ} \mathrm{C}, 16: 8 \mathrm{~h}$ light:dark and $75 \pm 5 \% \mathrm{RH}$ in a $30 \mathrm{~cm}$ high by $30 \mathrm{~cm}$ diameter arena made of 60 grit garnet sand paper with the garnet surface as the interior wall. A plate with damp vermiculite was used as the arena bottom and a knitting ring with cheesecloth was used as a cover. Inside the arena, a piece of kiwifruit, a single flower, a $10 \mathrm{~cm}$ shoot with 2-3 young leaves at the apex and a $10 \mathrm{~cm}$ woody vine with 2 old leaves of kiwifruit were placed. After 3 days, the number of eggs and egg masses deposited on the different parts of the plants was counted. Almost $95 \%$ of eggs were placed on the upper side of leaves with the remainder on twigs. No eggs were recorded on fruit or flowers. Significantly more masses $(\mathrm{P}<0.001)$ containing more than 63 eggs $(\mathrm{P}<0.001)$ were laid on old leaves than on young leaves. When allowed to choose between varieties, $C$. jactatana laid significantly more $(\mathrm{P}=0.03)$ and larger egg masses $(\mathrm{P}=0.01)$ on leaves of cv. Hayward than cv. Hort16A. 